\title{
The Future of Facilities Management: Managing Facilities for Sustainable Development
}

\author{
Alex Opoku ${ }^{1, *(\mathbb{D})}$ and Jeoung Yul Lee ${ }^{2}(\mathbb{D}$ \\ 1 Department of Architectural Engineering, College of Engineering, University of Sharjah, \\ Sharjah 27272, United Arab Emirates \\ 2 Department of Global Management, School of Business Management, Hongik University, Sejong 30016, Korea; \\ jeoungyul@hongik.ac.kr \\ * Correspondence: aopoku@sharjah.ac.ae
}

Citation: Opoku, A.; Lee, J.Y. The Future of Facilities Management:

Managing Facilities for Sustainable Development. Sustainability 2022, 14, 1705. https://doi.org/10.3390/ su14031705

Received: 27 January 2022

Accepted: 30 January 2022

Published: 1 February 2022

Publisher's Note: MDPI stays neutral with regard to jurisdictional claims in published maps and institutional affiliations.

Copyright: (C) 2022 by the authors. Licensee MDPI, Basel, Switzerland. This article is an open access article distributed under the terms and conditions of the Creative Commons Attribution (CC BY) license (https:// creativecommons.org/licenses/by/ $4.0 /)$.
Facilities management (FM) is currently shifting emphasis towards a long-term focus through the adoption of maintenance and operation practices that considers the social, environmental, and economic benefits of all business decisions. The FM sector is engaging with a sustainable development agenda as the whole built environment continues to evolve. Brochner et al. [1] argue that digitalization and sustainability are the two main forces that have shaped FM since the 1970s, and this is impacting on the role of facility managers. However, Abbas et al. [2] describe the perception of the FM professions as conservative as one of the challenges in adopting sustainability within the FM profession. A study by Collins et al. [3] that explored the gap between sustainable buildings and sustainable FM believe that there is a need to bridge the traditional gap between design, construction, and FM demands for more effective solutions based on life cycle assessments. The adoption of sustainable FM practices will reduce energy, water, and waste in the maintenance and operation of buildings. However, Lok et al. [4] add that organisational level support is required for the smooth adoption of sustainable FM practices and processes.

The concept of sustainable facilities management (SFM) brings together the two concepts of FM and sustainable development by adopting technology and innovative business practices that balances the social, economic, and environmental impacts of business decisions. The global challenges of climate change and the demand for energy efficiency is impacting on the call for the FM industry to devise and develop solutions that minimise the negative impact of buildings on the environment. There is therefore a critical need to retrofit and green the existing building stock.

The concept of SFM has been defined by many scholars, but Nielsen and Galamba [5] describe it as the consideration of the sustainability principles on core business, support function, and the impact on the local community of operation and the global community. However, Lee and Kang [6] provide a more detailed description of SFM to include the use of environmentally friendly materials that enhance indoor air quality, reuse of water, and efficient energy use that offer good thermal comfort, sustainable renovation and retrofitting, flexible design of developments that promote sustainable cities and communities, circularity, and so on.

Tucker [7] adds that SFM involves the management, implementation and the delivery of an organization's core and non-core business services that contribute to economic, social, and environmental sustainability. The FM sector should be at the heart of the engagement and drive towards integrating sustainability into day-to-day FM practices to achieve better services to customers. SFM is about the ability to make smart decisions that will minimise the negative impact of business decision on the environment by implementing sustainable practices across the business that addresses the 3Cs of FM, consisting of customer experience, climate change, and competition. Elmualim et al. [8] believe that facilities managers have a critical role to play in the adoption of sustainability principles in the 
wider built environment, and the FM sector in particular. However, the adoption and implementation of sustainability principles in FM requires collaborative partnership with the relevant stakeholders on effective strategies that promotes health, safety, and wellbeing practices in the organization. The adoption of sustainable FM practices could help address many FM challenges, simplifying the everyday FM work at strategic, tactical, and operational levels. This requires a more holistic plan that coordinates investment, administration, space management, operation, and service functions. Even though SFM seems to be biased towards technical and isolated environmental problems [4], FM organisations are progressively addressing environmental, social, and economic sustainability of their business activities simultaneously.

The benefit of SFM of existing facilities such as greening building stock will offer more benefits than delivering new sustainable construction projects as SFM promotes energy savings, waste reduction, water conservation, carbon footprint controls, and so on. The decision of a facility manager has the potential to either positively or negatively affect the planet [9]. At the forefront of organisational behavioural change is the facility manager who is in the position to influence the behaviour change of individuals working at all levels of business where they have the role to manage facilities [10]. Buser et al. [11] argue that $80 \%$ of a building's impact on climate change happens during the operation phase, highlighting the negative impact of a building operation on the environment. The built environment alone accounts for more than $33 \%$ of energy use, $40 \%$ of materials use, and produces $40-50 \%$ of greenhouse gas emissions globally. The SFM of existing building stock and infrastructure is essential in achieving the global agenda towards sustainability due to the volume of existing building stock [12,13].

SFM can help in addressing some of the global challenges such as climate adaptation, energy efficiency, and sustainable development developing innovative solutions for organisations and the society [14]. Even though the FM profession has a potential role to play towards the realisation of sustainable development goals, [15] argue that facility managers will require the development of the relevant knowledge and skills to be able to fully embrace the opportunities of integrating sustainability principles into core FM business strategies and operations. A study by the International Facility Management Expert Centre (IFMEC) [16] in the Netherlands revealed that strategic SFM has the potential for the realisation of the 17 Sustainable Development Goals because the FM profession has the advantage of incorporating the SDG's at all levels of organisation, from corporate to the operational levels, and can influence behavioural changes at the individual level by providing the enabling environment for sustainable practices.

By providing economic and social improvement for individuals through job creation (SDG 8-decent work and economic growth), the FM sector can also help address SDG 1 (no poverty). The FM profession is the heart of the food supply chain in many organisations including companies, schools, hospitals, and so on; co-creating the workplace and the working condition of employees, thereby addressing SDGs 2 (zero hunger) and SDG 3 (good health and well-being), respectively. The sector is also responsible for the sustainable maintenance of buildings in cities and communities (SDG 11-sustainable cities and communities), which includes managing building energy usage (SDG 7-affordable and clean energy) and the efficient management of water (SDG 6-clean water and sanitation) in buildings by reducing water losses through avoidable leakages. The FM profession is managing educational facilities globally, thereby improving quality education for all, SDG 4 (quality education). The FM sector continues to be a model for other sectors to follow in terms of its record of a diverse workforce of all nationalities (Goal 9-reduced inequalities), equal rights in wages and career opportunities for women, demonstrating gender equality (SDG 5) in the sector. The FM sector has done well by adopting relevant technologies such as artificial intelligence (AI), Internet of Things (IoT), etc., as parts of the sector's smart building agenda to support the realization of SDG 9 (industry, innovation, and infrastructure) [16]. 
The FM sector can contribute to the realisation of SDG 12 (responsible consumption and production) by promoting policies and practices that source food and other resources through sustainable and circular procurement strategies to ensure that only healthy products (eco-friendly) with no or minimum damage to health and the environment are used in the FM sector. For example, the FM sector should only buy wood-related products with a sustainable certificate to prevent the loss of biodiversity (Goal 15-life on land, biodiversity). Such policies and actions will lower the sector's $\mathrm{CO}_{2}$ emission and carbon footprint (Goal 13-climate action), which could be absorbed into oceans and seas (Goal 14-life below water), which is critical for the planet. The FM sector works in partnership with people, organisations and authorities (Goal 17-partnership for the goals) to maintain safety and security (Goal 16-peace, justice and strong institution) in and around building facilities [16].

Facility managers are urged to focus on the long-term environmental impact of business decisions as opposed to short-term maintenance issues of buildings. The heart of the SFM practice is the creation of net-zero energy buildings and the provision of innovative energy utilization solutions in existing building stock, integrating data-driven management technologies such as AI, IoT and machine learning (ML), adopting the circular economy concept by recycling plastic, the use of compost waste for landscaping, and delivering relevant waste-to-energy projects. Building automation through the use of smart technology in retail premises, offices and residential communities will result in efficient operation of building facilities. To ensure effective implementation of sustainability in the FM sector, the training of the workforce on best sustainability practices, policies, and procedures, and raising awareness among end-users, is essential. Sustainability practices should be incorporated into FM operations and functions, such as reducing water usage through the installation of automated toilets, waterless urinals, low flow, the use of locally grown food, waste disposal and recycling, and the use space management practices, such as hot-desking [17].

This Special Issue on "The Future of Facilities Management and Sustainable Development" resulted in the publication of the following 12 research papers:

1. Irina Canco, Drita Kruja and Tiberiu Iancu-AHP, a Reliable Method for Quality Decision Making: A Case Study in Business. It explores the use of the analytic hierarchy process (AHP) method as a reliable method for making decisions, both now and in the future.

2. Jeoung Yul Lee, Ilkhom Okmirzaevich Irisboev and Yeon-Sik Ryu-Literature Review on Digitalization in Facilities Management and Facilities Management Performance Measurement: Contribution of Industry 4.0 in the Global Era. The paper presents a comprehensive systematic review on digitalization (DT) in facility management (FM) and FM performance management (PM).

3. Wenmei Fei, Alex Opoku, Kofi Agyekum, James Anthony Oppon, Vian Ahmed, Charles Chen and Ka Leung Lok-The Critical Role of the Construction Industry in Achieving the Sustainable Development Goals (SDGs): Delivering Projects for the Common Good. This paper explores the role of the construction industry in achieving the 2030 Sustainable Development Goals.

4. Ka Leung Lok, Andrew Smith, Alex Opoku and Charles Chen-The Challenges of Sustainable Development on Facilities Management Outsourcing Services: An Investigation in Educational Facilities. The purpose of this paper is to study the concept of outsourcing relationships in relation to FM, and to investigate the design of the critical success factors on sustainable outsourcing strategies through a discussion of four dimensions (ownership of FM assets, control of FM assets, competitive position, and long-term plan).

5. Seungbeom Kim, Yooneun Lee and Byungchul Choi-Adoption of Satellite Offices in Response to a Pandemic: Sustainability and Infection Control. This paper addresses a satellite office allocation problem that considers social and environmental sustainability and infection control at work. 
6. Ryan Loeh, Jess W. Everett, William T. Riddell and Douglas B. Cleary-Enhancing a Building Information Model for an Existing Building with Data from a Sustainable Facility Management Database. This study investigates the feasibility and benefits of transferring data between Autodesk Revit (used for building information modeling (BIM)) and BUILDER SMS (used for sustainable facility management (SFM)).

7. Ka Leung Lok, Albert So, Alex Opoku and Charles Chen-A Sustainable Facility Management Outsourcing Relationships System: Artificial Neural Networks. The purpose of this paper is to thoroughly analyse the simulated case studies of the four different categories (i.e., in-house, technical expertise, commitment, and common goals) of the CORE model from the perspective of the various clients.

8. Waynika Tanpipat, Huey Wen Lim and Xiaomei Deng_-Implementing Remote Working Policy in Corporate Offices in Thailand: Strategic Facility Management Perspective. The study is aimed at exploring the effect of organizational norms on remote working, on remote work productivity, and organizational commitment among Thai employees.

9. Damjan Maletič, Matjaž Maletič, Basim Al-Najjar and Boštjan Gomišček-An Analysis of Physical Asset Management Core Practices and Their Influence on Operational Performance. This paper aims to examine the PAM core practices and the performance implications of integrating these practices into business, in particular by assessing their impact on operational performance.

10. Elizaveta Gavrikova, Irina Volkova and Yegor Burda—Strategic Aspects of Asset Management: An Overview of Current Research. The paper presents a systematic review of the existing research through the analysis of over 700 articles devoted to asset management with a focus on strategic aspects.

11. Vian Ahmed, Karam Abu Alnaaj and Sara Saboor-An Investigation into Stakeholders' Perception of Smart Campus Criteria: The American University of Sharjah as a Case Study. This research uses a set of comprehensive criteria to identify what it is perceived to be a Smart Campus and evaluate these criteria from the stakeholders' perception.

12. Zhenmin Yuan, Guodong Ni, Linxiu Wang, Yaning Qiao, Chengshuang Sun, $\mathrm{Na} \mathrm{Xu}$ and Wenshun Wang-Research on the Barrier Analysis and Strength Measurement of a Prefabricated Building Design. This research uses a set of comprehensive criteria to identify what it is perceived to be a Smart Campus, and evaluate these criteria from the stakeholders' perception.

Author Contributions: Conceptualization, A.O. and J.Y.L.; writing-original draft preparation, A.O. and J.Y.L.; review and editing, A.O. and J.Y.L. All authors have read and agreed to the published version of the manuscript.

Funding: This research received no external funding.

Institutional Review Board Statement: Not applicable.

Informed Consent Statement: Not applicable.

Data Availability Statement: Not applicable.

Conflicts of Interest: The authors declare no conflict of interest.

\section{References}

1. Brochner, J.; Haugen, T.; Lindkvist, C. Shaping tomorrow's facilities management. Facilities 2019, 37, 366-380. [CrossRef]

2. Elmualim, A.; Shockley, D.; Valle, R.; Ludlow, G.; Shah, S. Barriers and commitment of facilities management profession to the sustainability agenda. Build. Environ. 2010, 45, 58-64. [CrossRef]

3. Collins, D.; Haugen, T.; Lindkvist, C.; Aamodt, C. Bridging the gap between sustainable FM and sustainable buildings-an exploratory study of six public buildings in Norway. Facilities 2019, 37, 639-652. [CrossRef]

4. Lok, K.L.; Opoku, A.; Baldry, D. Design of sustainable outsourcing services for facilities management: Critical success factors. Sustainability 2018, 10, 2292. [CrossRef]

5. Nielsen, S.B.; Galamba, K.R. Facilities management-When sustainable development is core business. In 9th EuroFM Research Symposium; EFMC: Madrid, Spain, 2010. 
6. Lee, S.Y.; Kang, M. Innovation characteristics and intention to adopt sustainable facilities management practices. Ergonomics 2013, 56, 480-491. [CrossRef] [PubMed]

7. Tucker, M. Sustainable Facilities Management, in Total Sustainability in the Built Environment; Cotgrave, A., Riley, M., Eds.; Palgrave Macmillan: Basingstoke, UK, 2013.

8. Elmualim., A.; Valle, R.; Kwawu, W. Discerning policy and drivers for sustainable facilities management practice. J. Sustain. Built Environ. 2012, 1, 16-25. [CrossRef]

9. Aceves-Avila, C.D.; Berger-García, M.A. Sustainable facilities management in higher education institutions. In Encyclopedia of Sustainability in Higher Education; Leal Filho, W., Ed.; Springer: Cham, Germany, 2019.

10. Elmualim, A.A.; Czwakiel, A.; Valle, C.R.; Ludlow, G.; Shah, S. The practice of sustainable facilities management: Design sentiments and the knowledge chasm. Archit. Eng. Des. Manag. 2009, 5, 91-102.

11. Buser, M.; Støre-Valen, M.; Olsen, E.B.; Straub, M.; Lauridsen, K.A. Improving the implementation of sustainable facilities management: The role of end-users in realising energy efficient solutions. In Proceedings of the 17th EuroFM Research Symposium EFMC, Sofia, Bulgaria, 5-8 June 2018; Available online: https:/ / www.semanticscholar.org/paper/Improving-theimplementation-of-sustainable-the-of-Buser-St\%C3\%B8re-Valen/3dfcfb546283bc205703c89c1b96088ed66e263b (accessed on 26 January 2022).

12. Nielsen, S.B.; Jensen, J.O.; Jensen, P.A. Delivering sustainable facilities management in Danish housing estates. In Proceedings of the CIMNE 2009 international conference on Sustainability Measurement and Modelling, Barcelona, Spain, 5-6 November 2009.

13. Radebe, S.; Ozumba, A.O.U. Challenges of implementing sustainable facilities management in higher institutions of learning. In IOP Conference Series: Earth and Environmental Science; IOP Publishing: Bristol, UK, 2021.

14. Nielsen, S.B.; Sarasoja, A.-L.; Galamba, K.R. Sustainability in facilities management: An overview of current research. Facilities 2016, 34, 535-563. [CrossRef]

15. Kwawu, W.; Elmualim, A. Sustainability in facilities management: A review of drivers and policy issues. In Proceedings of the 27th Annual ARCOM Conference, Bristol, UK, 5-7 September 2011; Egbu, C., Lou, E.C.W., Eds.; Association of Researchers in Construction Management: Reading, UK, 2011; pp. 1185-1194.

16. IFMEC. Facility Management Approach to Realizing the Sustainable Development Goals; International Facility Management Expert Centre (IFMEC): Roden, The Netherlands, 2018.

17. Berardi, U. Sustainability assessment of urban communities through rating systems. Environ. Dev. Sustain. 2013, 15, 1573-1591. [CrossRef] 